Portland State University

PDXScholar

\title{
A Descriptive Study of Demography \& Transportation Issues of Chronically Mentally III in the Eastern Oregon Comprehensive Community Mental Health Catchment Area
}

Tom H. Brubaker

Portland State University

David Emmons

Portland State University

John Meade

Portland State University

Follow this and additional works at: https://pdxscholar.library.pdx.edu/open_access_etds

Part of the Psychiatric and Mental Health Commons, and the Social Work Commons Let us know how access to this document benefits you.

\section{Recommended Citation}

Brubaker, Tom H.; Emmons, David; and Meade, John, "A Descriptive Study of Demography \&

Transportation Issues of Chronically Mentally III in the Eastern Oregon Comprehensive Community Mental Health Catchment Area" (1979). Dissertations and Theses. Paper 2817.

https://doi.org/10.15760/etd.2812

This Thesis is brought to you for free and open access. It has been accepted for inclusion in Dissertations and Theses by an authorized administrator of PDXScholar. Please contact us if we can make this document more accessible: pdxscholar@pdx.edu. 
A DESCRIPTIVE STUDY OF DEMOGRAPHY \& TRANSPORTATION ISSUES

$$
\text { OF CHRONICALLY MENTALLY ILL IN THE }
$$

EASTERN OREGON COMPREHENSIVE COMMUNITY MENTAL HEALTH CATCHMENT AREA

$$
\text { by }
$$

TOM H. BRUBAKER

DAVID EMMONS

JOHN MEADE

A practicum submitted in partial fulfillment of the requirements for the degree of

MASTER OF SOCIAL WORK

Portland State University

1979 
APPROVED: Nancy KorøToff, Project \$irector Regional Research Institute 
TABLE OF CONTENTS

PAGE

LIST OF TABLES ......................... iv

INTRODUCTION . . . . . . . . . . . . . . . . 1

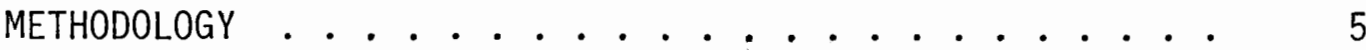

DISCUSSION ............................ 11

Methodology ................ 11

RESULTS/TOTAL SAMPLE . . . . . . . . . . . . 17

Demographic Information . . . . . . . . 17

Diagnosis ................ . . 19

Criteria ................ . . 22

Criteria: Comparison of Interviewed to
Non-Interviewed Subjects .....

RESULTS/INTERVIEWED SAMPLE . . . . . . . . . . . . 25

Demographic Information .......... 26

Diagnosis ................ . . . 32

Transportation Data ............ . . 34

Criteria ............... 41

DISCUSSION OF RESULTS ................... 43

IMPLICATIONS AND CONCLUSIONS . . . . . . . . . 47

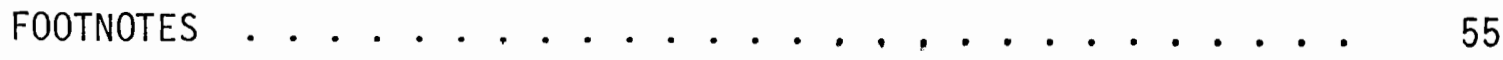

BIBLIOGRAPHY . . . . . . . . . . . . . 56

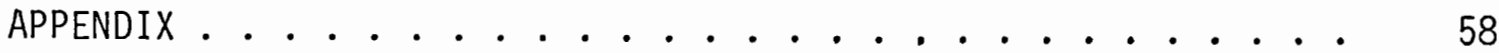




\section{LIST OF TABLES}

TABLE

PAGE

I Age of Total Sample--Umatilla/Non-Umatilla . . . 18

I Age of Total Sample--Male/Female . . . . . . . . 18

II Ethnic Group of Total Sample . . . . . . . . . 19

IV Diagnosis Total Sample--Male/Female . . . . . . 20

V Non-Umatilla/Breakdown by County . . . . . . 21-22

VI Criteria for Total Sample (All Counties) . . . . . 23

VII Criteria by Diagnosis, Interviewed and

Non-Interviewed . . . . . . . . . . .

VIII Umatilla/Non-Umatilla by Age . . . . . . . . .

IX Umatilla/Non-Umatilla by Sex . . . . . . . . 26

X Number of Dependents . . . . . . . . . . . 27

XI Marital Status . . . . . . . . . . . . 27

XII Ethnic Group . . . . . . . . . . . . . . 28

XII Educational Level . . . . . . . . . . . 28

XIV Income Level . . . . . . . . . . . . . . 29

XV Income Source . . . . . . . . . . . . . 30

XVI Type of Residence . . . . . . . . . . . . . 31

XVII Living Arrangement . . . . . . . . . . . . 31

XVIII Place of Residence . . . . . . . . . . . 32

XIX Interviewed Supjects by Diagnoṣjs . . . . . . . 33

XX Client Reported Use of Social Services . . . . . 34 
XXI Frequency of Use of Community Mental Health

Centers Per Month . . . . . . . .

XXII Health Limitations of Clients as They Affect

Transportation to CMHC Services .......

XXIII Mode of Transportation Used by Client to Receive

Mental Health Services .........

XXIV Mode of Transpertation to Mental Health Services

That Clients Were Aware of .......

XXV Geographic \& Climatic Barriers with Regard to

Transportation to Community Mental Health

Services ............. .

XXVI Distance Traveled for Mental Health Services

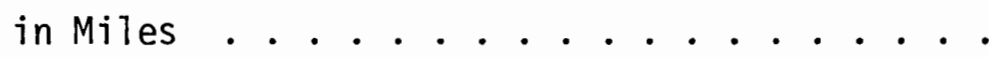

XXVII Psychological Barriers of Client With Regard to

Receipt of Mental Health Services ......

XXVIII Criteria by Sex.............. 
INTRODUCTION

The CMI (Chronically Mentally I11) experience many problems in obtaining services in both rural and urban environments. Such problems include community resistance to the mentally $\mathbf{1 1 1}$, inadequate treatment services, support systems, a lack of service utilization, and a lack of follow-up studies concerning this population, especially in rural areas. ' While these problems are generally characteristic of all areas of the country, whether urban or rural, they tend to have extreme manifestations in rural areas. Such problems are also conjoint in rural areas with rural life poverty, isolation, transportation difficulties, and sparse populations. ${ }^{2}$ In order to understand the possible barriers to mental health services in rural areas, this study will concern itself with certain demographic data and possible transportation difficulties of the CMI population in the rural environments. Our geographical target area is Eastern Oregon Comprehensive Community Mental Health Center catchment area of the State of Oregon, Mental Health Division. The target population will be recent releasees from Eastern Oregon State Hospital (EOSH) who reside in this region.

A review of literature on rural mental health reveals a general lack of information in comparison to research and literature on the urban counterpart. It is remarkable that before the 1970's little rural mental health research was done; however, with the '70's, the recognition of the need for information and understanding of the needs 
of rural CMI population has gained impetus.

Recent literature addresses itself to a variety of subjects, including transportation. The literature on transportation is limited and subjective. The predominate issue in the literature appears to be finances, or the lack of finances to adequately fund rural mental health services. The 1 iterature reviewed in relation to transportation gives limited accounts of transportation as a problem in rural areas. However, it discusses alternative client transportation systems and describes consultation services, satellite offices and traveling staff. An example of the literature is an article describing a consultation model in Southeast Nebraska which utilized clergymen, teachers, and various lay people to reach people in need of mental health services. The goal of the program was to provide a competent cadre of services to clients in outlying rural areas. Follow-up studies of this model concluded that the program was a success in reaching isolated clients and inducing community involvement. The study also found smal1 rural communities possess sufficient resources to provide adequate resources for the Chronically Mentally 111 in rural areas. ${ }^{3}$ Cohen alsa discusses transportation as an issue in people gaining services, however, not as an overwhelming concern.

Stackhouse provides some demographic information concerning the CMI population in Eastern Oregon, however, the information is limited to Umatilla County and only briefly discusses transportation as an issue. $^{4}$ In a 1978 study, Welsh and Kline-Skei discuss various problems of the CMI population in Fastern Oregon, again, this information is limited to Umatilla County. ${ }^{5}$ Because of the vastness of the region, 
little research has been done on the total area. Along with transportation data, demographic information on the CMI population in this total area is needed in order to design mental health services.

Adding further to the need for demographic information in rural areas is the "back to the country" movement. With the movement of individuals back to country residence come new issues of mental health related problems to rural areas, hence the predictive quality of psychological sequelae becomes difficult to understand. ${ }^{6}$ With rural areas beginning to absorb clientele from urban centers comes the need for further study of demographic variables in rural sections of the country. ${ }^{7}$

Mental health centers in Eastern Oregon sense the complexity of the deinstitutionalization process and the necessity for realistic planning based on the total needs of the community. Such realistic planning may make the needs of the CMI more easily managed in rural areas, and the advancement of mental health resources more readily realized. No one will deny that there are difficulties in effecting community care for CMI in cities. In rural areas, however, in order to build an effective system of community-based mental health care, one must consider the exjsting demographic and socio-economic factors which are present. ${ }^{8}$ In understanding demographic information, it is important to keep in mind the three general principles of the deinstitutionalization movement: 1) That community-based care is preferable to institutionalized care; 2) That the community must be able to assume the responsibility of the $\mathrm{CMI} ; 3$ ) That the community assume many of the mental hospital functions. ${ }^{9}$ 
New and creative ways of dealing with deinstitutionalized clients in rural areas are needed. Ways are needed in strengthening resources which are now present but are not being utilized to their fullest extent. In response to the need for more information concerning transportation and demographics, a research project was devised which covers some of these areas and will give new data that we hope will be valuable in planning for the CMI population in Eastern Oregon. 
METHODOLOGY

This study was formulated to elicit basic demographic information on the chronically mentally ill population in the Eastern Oregon Comprehensive Community Mental Health Center's catchment area, as well as information regarding their use of transpoptation modes for obtaining mental health services.

To accomplish this project, eight basic sequential steps were followed. They are as follows:

1. Cooperative Contact with State Mental Health Division Community Support Strategy Development Project.

The Community Support Program (CSP) is one of sixteen National Institute of Mental Health funded CSP's located throughout the United States. Oregon has one which operates at the state level. The programs are funded for one year, with the passibility of funding for two additional years.

The CSP of Oregon State Mental Health Division stated (April 25, 1978) as their basic goals was ". . . to help devise a network of people in the community compitted to assisting the chronic mentally and emotionally disabled adult to meet his/her needs and develop his/her potential without being unnecessarily isolated or excluded from the community (NIMH, 1977). In order to achieve this goal, various subgoals must be achieved. They include: (1) Definition of the target population, (2) Identiffacation of needs and potential of target population, (3) Assessment of services currently available for target 
population, (4) Identification of undeveloped community resources,

(5) Legislative, financial, and administrative cooperation."

Meetings were held with Carol Cordes, M.S., (Director) and David Langenes, Ph.D. (Researcher) to inform and develop our interest in conjunction with their research needs. Mutual goals were ascertained and agreements were formalized for product deadlines.

To insure research continuity, the CSP criteria for defining chronic MED (Mentally and Emotionally Disabled) was used, hereafter designated CMI (Chronically Mentally I11), (see Appendix).

\section{State Mental Health Division Sanction for Official Release of Information.}

A written request was submitted to J. D. Bray, M.D., Administrator for the Oregon Mental Health Division. Formal authorization was granted under state provision, ORS 179.505 (4) (6) allowing the researchers access to Eastern Oregon State Hospital MED patient files for the designated purposes of the study (see Appendix):

\section{Formal Sanction from the Eastern Oregon Mental Health Directors Association.}

These researchers met with the Directors Association during their monthly meeting in Pendleton, Oregon. Members included clinic director of the thirteen (13) counties, staff from the Eastern Oregon Comprehensive Community Mental Health Center and the Clinical Director of Eastern Oregon State Hospital. At this meeting the members of the research team, including one of the research advisors, presented both written and verbal information regarding the research purposes, goals and tentative metholodolagy. A mutual discussion ensued encompassing a 
general critique, as well as helpful suggestions, to facilitate procedures of patient tracking and data gathering. In addition, overall sanction for conducting the study was granted.

\section{Sampling Procedure.}

Subjects selected for study were drawn from all MED patients discharged from EOSH during the calendar year beginning June 1, 1977, to May 31,1978 . To qualify, subjects must meet the CSP criteria for CMI (see Appendix). Within this: sample S's (Subjects) must be residing in one of the thirteen (13) counties of Eastern Oregon Comprehensive Community Mental Health Center catchment area. Those S's diagnosed with primary alcoholism, drug abuse, organic brain. dysfunction (syndrome) and senile dementia were not included in the study group for the CSP report. Because Umatilla County accounts for approximately 50\% (fifty percent) of all EOSH admissions and releases and the county's population is the most dense, a 50\% (fifty percent) random sample of criteria qualified subjects were selected for interviewing in that specific county. This comprised 39 (thirty-nine) S's.

After the initial introduction and orientation to the EOSH medical records library staff, the research team used a computer printout to identify all MED discharges for the designated time period. This delineated the individuals' names, file number, date of release and type of release.

At that point, each individual's EOSH file was located, hand retrieved and scanned for confirmation or rejection under CSP residence criteria. To obtain the appropriate information from patient charts, eight sections were scanned as follows: admission sheet, notice of 
release, admission file card, physician discharge summary, social history, and progress notes. When criteria was confirmed, the S'S information was recorded and each $S$ was assigned a coded I. D. number. The coded I. D. number was utilized to insure confidentiality of client's name and address. The information included name, age, sex, race, probable destination and phone number, if known, county referral source, and date released.

\section{Formulation of Interview Questionnaires.}

Two interview questionnaires were designed. One questionnaire (see Appendix) was designed to gather information from the clients. The client questionnaire included demographic information, as well as data regarding transportation used and availability, distance to service and specific geographic and climatic features.

The second questionnaire (see Appendix) was designed to gather soft data from each mental health clinic regarding overall number of active CMI clients in treatment, coordination of hospital follow up and clinic policies regarding transportation of patients to and from mental health services.

The client questionnaires were pretested by the research team at the University of Oregon Health Sciences Center's Psychiatric Crisis Unit. Five questionnaires were administered and the results and process of the interview were evaluated and efficacious changes made.

\section{Tracking of Subjects.}

Each of the 13 (thirteen) County program staff were contacted either by phone or letter to arrange a time for the research inter- 
viewer to visit with staff and gather data. Usually a list of prospective S's was provided to the clinic staff prior to the visit to facilitate subject tracking and personal interview permission.

Final tracking of S's was accomplished either through firsthand knowledge of the clinic staff or by quick review of the S's chart. In some instances, tracking entailed contacting relatives or other service agencies involved with the client. S's not located were dropped from the study.

\section{Gathering and Recording Data.}

Subject Data: Most county agencies preferred to make contact initially with the S's to obtain final permission for a personal interview. In addition, it was left up to the clinicians' judgement to delete a personal interview if it would either jeopardize the S's ongoing involvement with the clinic or the S's psycho-social functioning. For those S's not personally interviewed, data was collected both from the primary clinician and patient chart. Interviews with subjects were done either at the mental health clinic or at the S's residence. A verbal or written release of information was obtained from each subject. This data was recorded on the S's questionnaire and identified with a corresponding coding number to ensure confidentiality.

Mental Health Clinic Data: Each client's post hospitalization out-patient clinician was personally interviewed and the data recorded on the Mental Health Clinic questionnaire (see Appendix). In two instances, the interviews were conducted by telephone. 
8. Tabulation of Data.

A11 S's and Clinic questionnaires were compiled and hand tabulated for results. 


\section{DISCUSSION}

\section{Methodology:}

The most obvious problem with this project's methodology was the researchers' naivete concerning Eastern Oregon Comprehensive Community Mental Health Center Catchment area prior to beginning the study. The researchers made several assumptions about the area which were the basis for the procedure used in obtaining the sample of chronically mentally ill subjects.

In reference to the methodology section (Page 5 ), it was the researchers' assumption that the most effective method to identify and locate the chronically mentally $i 11$ subjects was through the EOSH medical records and track them back to the communities for interviews. This was decided both from the researchers' personal experience with Region I's mental health system, as well as from knowledge of previous studies reviewed in the literature. The premise being that the CMI clients often did not make contact or follaw through with community mental health agency programs, and that community mental health agencies in Region I are so overtaxed for MED service that they could have less up-to-date knowledge of the location of CMI clients. It was also assumed that the agency staff would have less time to assist the researchers in their endeavor to locate subjects.

However, it was found that in Eastern Oregon Comprehensive Community Mental Health Center Catchment area the community mental health clinics were by far the most knowledgeable and accurate information 
source for identifying and tracking the CMI population. Apparently, this was due to the rural environment with its: overall low density of population; centralization of population within mental health clinic location site (usually the largest population center of the county); the predominant identification and referral of CMI from county program to EOSH; and the regular ongoing telephone or in person liaison between community mental health clinics and EOSH.

For future studies in this area, it is the researchers' belief that the most efficient method for identifying, tracking and sampling the CMI population would be to go directly to each of the community mental health clinics, thus bypassing EOSH altogether. This would be basically advantageous in three concerns--1) time, 2) more initial client information, and 3) identification of a larger total sample of CMI to draw from. This larger expected sample would be due to the inclusion of the chronically mentally ill population not hospitalized and/or released during our sample year of $6 / 1 / 77$ to $5 / 31 / 78$.

It must be mentioned that it was the researchers' impression that the community mental health clinics of the Eastern Oregon Comprehensive Community Mental Health Center Catchment area appear to pride themselves in reducing "red tape" and bureaucratic variables to a minimum. Personal contact, both formal and informal, is highly valued as is the informal communication network, i.e. "by word of mouth." From our observations, this was not only congruent with Eastern Oregon's rural community values, but has also been highly accurate in its transmission of information.

As with any study, the use of objective criteria is imperative 
in order to adequately and consistently define factors for study. CSP established certain criteria for the identification of the chronically mentally $i 11$ population. They were as follows:

I. Mental or Emotional Disability (must meet at least one criterion)

A. ( - Has had a single episode of hospitalization of at least 6 months' duration for treatment of a mental or emotional disturbance between 1973 and the present.

B. (-) Has had a total of 12 months of hospitalization for treatment of a mental or emotional disturbance between 1973 and the present.

c. (-) In the opinion of an experienced clinician, is severely mentally disabled.

AND

II. Impaired Functioning in the Natural Environment (must meet at least two criteria)

A. (-) Is unemployed with markedly limited job skills and/or a poor work history.

B. (-) Is employed in a sheltered setting.

C. (-) Is unable to perform basic household management tasks without assistance.

D. (-) Exhibits inappropriate social behavior which results in rejection by the community and requests for intervention by the mental health or judiciall/legal system.

E. (-) Is unable to procure appropriate public support services without assistance.

F. (-) Requires public financial assistance for out-of-hospital maintenance (SSI, General Assiștance, etc.)

G. (-) Severely lacks social support systems in the natural environment (no close friends, lives alone, no group affiliations, highly transient).

H. ( I) Is placed in a nursing home setting because of financial considerations and/or because a jess restrictive suitable environment isn't currently available. 
In this study we found that the CSP definition and criteria for defining the CMI population was most useful in two regards. First, it aided the researchers in maintaining continuity between studies. Second, it provided a working definition for CMI, both broad in nature and yet objectifiable.

In many previous studies the CMI population has been defined only by diagnosis or time and number of hospitalizations. This method has three major shortcomings. First, physicians vary in their use of diagnostic techniques. Second, since deinstitutionalization began, psychiatric hospitals have changed markedly in their treatment philosophies and procedures. Years ago, it was common for an individual needing in-patient care to be hospitalized for a year or even several years. Today it is more typical for an individual to have one or several short (1-2 week) hospitalizations over several years time. Third, some individuals reasonably judged to be CMI may have never been hospitalized due to the community-based support system's success with the individual.

The CSP criteria (Section I) included individuals whom have either had long-term hospitalization or several short hospitalizations. In addition, it included a more subjective category, i.e., IC, "In the opinion of an experienced clinician, is chronically mentally i1l." Although subject to critjcism because of its subjective nature, it does encompass a broader, more inclusive picture of the individual's longitudinal level of psycho-social functioning. Individuals in this category were confirmed by reviewing the medical records at Eastern Oregon State Hospital and determining whether the physician described 
the individuals as chronic in the diagnostic summary. If it was uncertain whether the client met this criteria, the community mental health clinic (providing the follow-up care) records and staff were consulted for further information regarding the nature and course of the client's dysfunction.

In our total sample, for instance, approximately $73 \%$ of what we identified as the CMI population would have been missed if only items IA (single episode of 6 or more months hospitalization) and IB (12 or more months of hospitalization since 1973) were used as identifying criteria.

It is interesting to note that Items $A$ and $B$ or long term and/or frequent hospitalizations seem to be related to geographic stability. In other words, the chronically mentally ill people who continue to live in one specific place are more likely to have a history of frequent or long-term hospitalization. A possible problem with this correlation is that we may have had inaccurate information regarding previous hospitalizations for the more transient individuals.

Furthermore, the CSP definition also included a criteria section of impaired functioning in the environment such as unemployed, inability to perform basic household tasks, etc. In this section, two criteria must be met in support of the criteria met in Section I.

After using the CSP definition to review approximately 500 individuals both at the EOSH and community mental health clinics of Eastern Oregon Comprehensive Community Mental Health Center Catchment area, it was our conclusion that the CSP criteria for identifying the CMI population was valid, reliable, and easy to use. The only ex- 
ception to this was its use of EOSH's medical records. Here, an individual's confirmation of criteria under Section II was often difficult or impossible to ascertain. This was generally due to a lack of recorded information about the individual's psycho-social functioning in the community. 


\section{RESULTS/TOTAL SAMPLE}

Out of the total discharges released from EOSH during the period June 1, 1977, to May 31, 1978, 97 individuals met the CSP criteria which was established to identify the chronically mentally 111 (CMI) population.

Out of these total discharges, thirty-six individuals were interviewed and as a result, comprise our interviewed sample. The interviewed subjects were chosen primarily on the basis of availability.

of the total sample, fifty-two (54\%) were discharged to Umatilla County and forty-five were released to ten of the remaining twelve counties in the defined catchment area.

Demographic Information:

The subjects' ages ranged from 18 years to 67 years. The average age of the Umatilla group was 37.9 and the average age of the nonUmatilla group was 34.5 . 
TABLE I

AGE OF TOTAL SAMPLE--UMATILLA/NON-UMATILLA

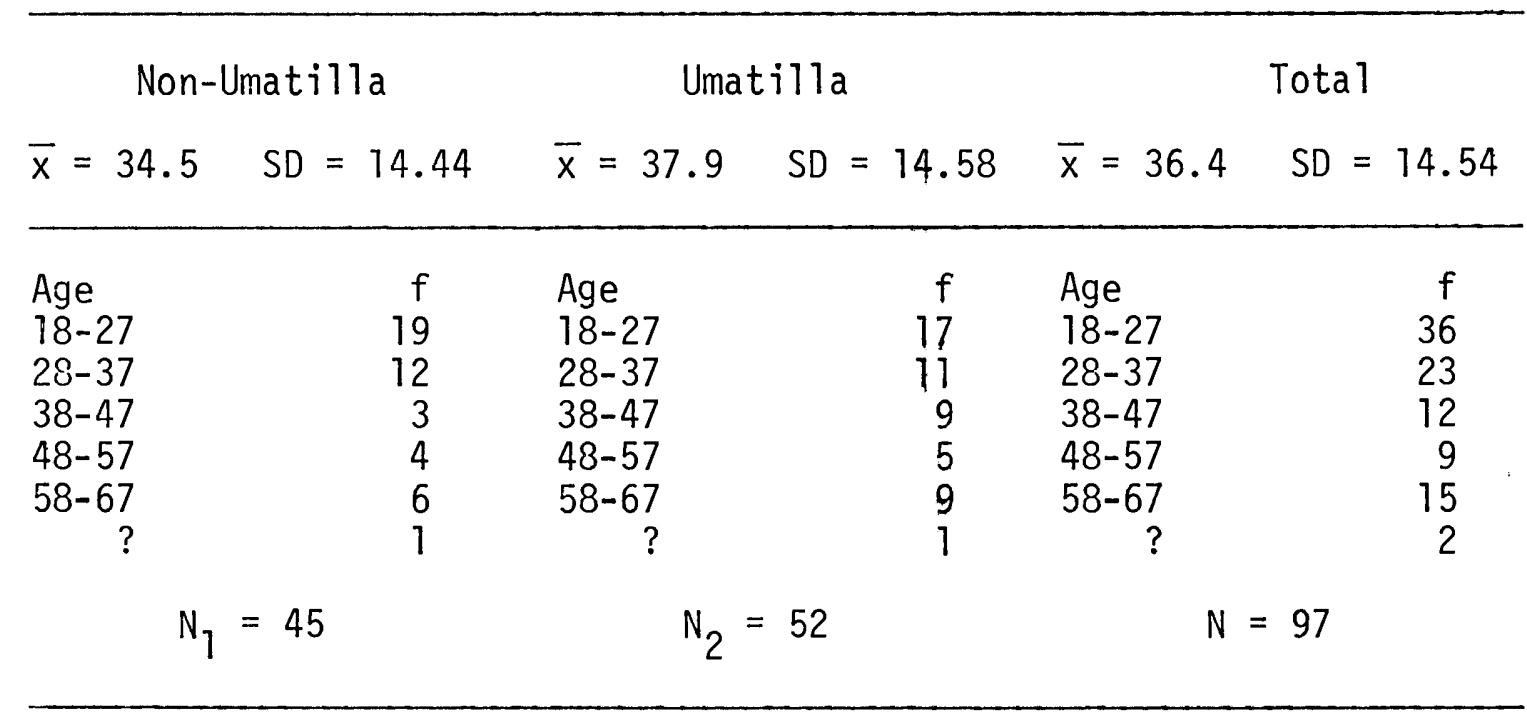

There were 48 males and 49 females. The average age of male subjects was 32.8 and the average age of the female subjects was 39.9.

\section{TABLE II}

AGE OF TOTAL SAMPLE--MALE/FEMALE

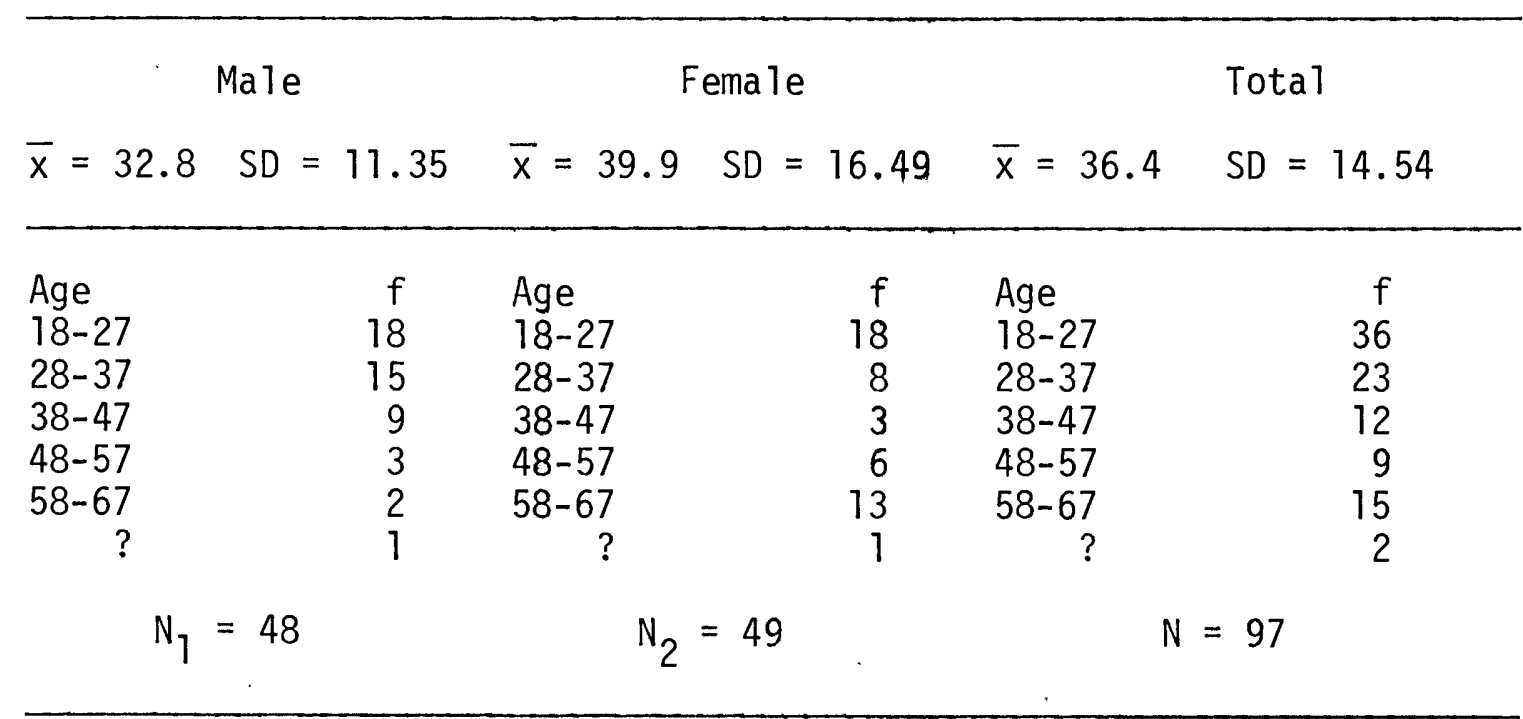

$?=$ Age of individual unknown. 
Ninety-four or $97 \%$ of the total sample were of white ethnicity. One individual was American Indian and two were Mexican American.

\section{TABLE III}

ETHNIC GROUP OF TOTAL SAMPLE

$$
\begin{aligned}
\text { White } & =94 \\
\text { American Indian } & =1 \\
\text { Mexican American } & =2 \\
N & =97
\end{aligned}
$$

Diagnosis:

There were nine separate diagnostic categories included in the total sample (see Table IV). Fifty-two or $54 \%$ of the subjects were diagnosed as Chronic Undifferentiated Schizophrenics and 21 or $22 \%$ of the subjects were diagnosed as paranoid schizophrenics. 'The major psychotic dysfunctions comprised $96 \%$ of the total sample, i.e., Chronic Undifferentiated Schizophrenia, Paranoid Schizophrenia, Simple Schizophrenia, and Manic Depressive I17ness. There were forty-one males and forty-two females in these four diagnostic categories. 
TABLE IV

DIAGNOSIS TOTAL SAMPLE--MALE/FEMALE

Diagnos is

Male Female Total \%

\begin{tabular}{lrrrr}
\hline Chronic Undifferentiated Schizophrenia & $f$ & $f$ & $f$ & \\
Paranoid Schizophrenia & 27 & 31 & 52 & $54 \%$ \\
Simple Schizophrenia & 16 & 5 & 27 & $22 \%$ \\
Manic Depressive Illness & 1 & 4 & 5 & $5 \%$ \\
Schizoaffective Disorder & 3 & 2 & 5 & $5 \%$ \\
Schizoid Personality & 2 & 4 & 6 & $6 \%$ \\
Paranoid Personality \& Alcohol Dependency & 7 & 0 & 1 & $1 \%$ \\
Depressive Neurosis & 3 & 0 & 1 & $1 \%$ \\
Hysterical Neurosis & 0 & 1 & 5 & $5 \%$ \\
& & 1 & $1 \%$ \\
\hline
\end{tabular}

$$
N_{1}=48 N_{2}=49 \quad N=97
$$

Of the 45 subjects released outside of Umatilla County, nine were released to Baker County, five to Grant County, one to Harney County, one to Hood River County, ten to Malheur County, three to Morrow County, five to Union County, four to Wallowa County, seven to Wasco County, one to wheeler County. There were no subjects released to Gilliam and Sherman Counties.

Thirty-six or $80 \%$ of the subjects in the non-Umatilla group were diagnosed as having one of the major psychotic dysfunctions (Chronic Undifferentiated Schizophrenics, Paranoid Schizophrenics, Simple Schizophrenics, or Manic Depressives). There were twenty-five females and twenty males in the non-Umatilla group. There were 44 white subjects and one American Indian subject. 
TABLE $V$

NON-UMATILLA/BREAKDOWN BY COUNTY

\begin{tabular}{|c|c|c|c|c|c|c|}
\hline \multirow[t]{2}{*}{ County } & \multirow[t]{2}{*}{ Age } & \multicolumn{2}{|c|}{ Sex } & \multicolumn{2}{|c|}{$\begin{array}{l}\text { Ethnic } \\
\text { Group }\end{array}$} & \multirow[t]{2}{*}{ Diagnosis } \\
\hline & & & $f$ & & $f$ & \\
\hline $\begin{array}{l}\text { Baker } \\
N=9\end{array}$ & $\begin{array}{ll}28 & 25 \\
29 & 33 \\
19 & 59 \\
44 & 21 \\
47 & \end{array}$ & $\begin{array}{l}F \\
M\end{array}$ & $\begin{array}{l}6 \\
3\end{array}$ & W & 9 & $\begin{array}{l}\text { Paranaid Schizophrenia - } 3 \\
\text { Depressive Neurosis - } 2 \\
\text { Paranaid Personality \& ETOH - } 1 \\
\text { Chronic Undifferentiated } \\
\text { Schizophrenia - } 1 \\
\text { Schizadfective Disorder - } 2\end{array}$ \\
\hline
\end{tabular}

Gilliam

$\mathrm{N}=0$

$\begin{array}{lllllllll}\text { Grant } & 60 & 57 & F & 5 & \text { W } & 5 & \begin{array}{c}\text { Simple Schizophrenia }-3 \\ \text { Chronic Undifferentiated } \\ \text { Schizophrenia }-2\end{array} \\ & 61 & 62\end{array}$

Harney $\quad 59 \quad$ M 1 I 1 Paranoid Schizophrenia - 1 $\mathrm{N}=1$

Hood River $29 \quad M \quad 1 \quad$ W 1 Chronic Undifferentiated $\mathrm{N}=1$ Schizophrenia - 1

$\begin{array}{llllllll}\text { Malheur } & 56 & 24 & \mathrm{~F} & 5 & W & 10 & \begin{array}{c}\text { Paranaid Schizophrenia }-2 . \\ \mathrm{N}=10\end{array} \\ 23 & 36 & \mathrm{M} & 5 & & & \begin{array}{c}\text { Manic Depressive }-2 \\ \text { Simple Schizophrenia }-2\end{array} \\ & 25 & 28 & & & & & \begin{array}{c}\text { Chronic Undifferentiated } \\ \text { Schizophrenia }-4\end{array} \\ & 29 & 35 & & & & & \end{array}$

\begin{tabular}{|c|c|c|c|c|c|c|}
\hline $\begin{array}{l}\text { Morrow } \\
N=3\end{array}$ & $\begin{array}{l}22 \\
22\end{array}$ & $\begin{array}{l}F \\
M\end{array}$ & 1 & $W$ & 3 & $\begin{array}{l}\text { Depressive Neurosis - } 1 \\
\text { Schizoaffective Disorder }-1 \\
\text { Paranoid Schizophrenia }-1\end{array}$ \\
\hline
\end{tabular}

Sherman

$\mathrm{N}=0$ 
TABLE V (CONT.)

NON-UMATILLA/BREAKDOWN BY COUNTY

\begin{tabular}{|c|c|c|c|c|}
\hline \multirow[t]{2}{*}{ County } & Age & Sex & $\begin{array}{l}\text { Ethnic } \\
\text { Group }\end{array}$ & Diagnosis \\
\hline & & $f$ & $f$ & \\
\hline
\end{tabular}

\begin{tabular}{|c|c|c|c|c|c|c|}
\hline $\begin{array}{l}\text { Union } \\
N=5\end{array}$ & $\begin{array}{ll}32 & 29 \\
49 & 34\end{array}$ & $\begin{array}{l}F \\
M\end{array}$ & 2 & W & 4 & $\begin{array}{c}\text { Chronic Undifferentiated } \\
\text { Schizophrenia - } 2 \\
\text { Depressive Neurosis - } 1 \\
\text { Paranaid Schizophrenia - }\end{array}$ \\
\hline
\end{tabular}

Wallowa $\quad 5120 \quad \mathrm{~F} \quad 0 \quad \mathrm{~W} \quad 4$ Paranoid Schizophrenia - 3 $\mathrm{N}=4 \quad 2923 \quad \mathrm{M} \quad 4 \quad$ Chronic Undifferentiated Schizophrenia - 1

\begin{tabular}{|c|c|c|c|c|c|c|}
\hline $\begin{array}{l}\text { Wasco } \\
N=7\end{array}$ & $\begin{array}{ll}24 & 24 \\
19 & 24 \\
29 & 43 \\
26 & \end{array}$ & $\begin{array}{l}F \\
M\end{array}$ & $\begin{array}{l}4 \\
3\end{array}$ & $W$ & 7 & $\begin{array}{l}\text { Chronic Undifferentiated } \\
\text { Schizophrenia - } 3 \\
\text { Manic Depressive I1lness - } 2 \\
\text { Paranoid Schizophrenia - } 1 \\
\text { Schizoaffective Disorder - } 1\end{array}$ \\
\hline
\end{tabular}

Wheeler

23

F 1 W 1

Chronic Undifferentiated

$\mathrm{N}=1$

Schizophrenia - 1

$N=45 \quad \begin{array}{ll}F=25 & W=44 \\ M=20 & I=1\end{array}$

$W=$ White

$I=$ American Indian

$\mathrm{F}=$ Female

$M=$ Male

Criteria: (See page 10 and 11)

Seventy-one or $73 \%$ of the total sample of ninety-seven subjects were identified by using Item IC of the criteria established by CSP. With Item IC the person was identified as one of our sample popula- 
tion if it was the opinion of an "experienced clinician" that he or she was chronically mentally $i 11$.

Eighty-nine (92\%) of the total sample included Item II A, which identified subjects on the basis of their being unemployed with "1imited job skills and/or a poor work history."

Fifty-nine $(61 \%)$ of the total sample included Item II D, which identified subjects on the basis of "inappropriate social behavior which results in rejection by the community and requests for intervention by the mental health or judicial/legal system."

TABLE VI

CRITERIA FOR TOTAL SAMPLE

(ALL COUNTIES)

\section{$f$}

$\begin{array}{ll}\text { I } A, & \text { II } A B=5 \\ \text { I } A, \text { II } A D=1 & =1 \\ \text { I } B, \text { II } A C=6 \\ \text { I } B, \text { I I } A D=13 \\ \text { I } B, \text { II } A G=1 \\ \text { I C, II } A C=8 \\ \text { I C, II } A D=37 \\ \text { I C, II } A F=1 \\ \text { I C, II } A G=17 \\ \text { I C, II CD }=5 \\ \text { I C, II } D G=3 \\ \end{array}$

Criteria: A Comparison of Interviewed and Non-Interviewed Subjects.

Thirteen or $50 \%$ of the total number of Criteria I A and I B were included in the interviewed sample of thirty-six subjects. Twenty-three or $32 \%$ of the total number of criterion I C were included in the interviewed sample. 
Items I A and I B accounted for $21 \%$ of the non-interviewed sample, while they accounted for $36 \%$ of the interviewed sample. Item I C of the criteria accounted for $64 \%$ of the interviewed sample and $79 \%$ of the non-interviewed sample. See Table 7.

TABLE VII

CRITERIA BY DIAGNOSIS

INTERVIEWED/NON - INTERVIEWED

Diagnosis Interviewed Non-interviewed Totals

\begin{tabular}{lllll}
\hline Chronic Undifferentiated & I A, & f & f & I A, 3 \\
Schizophrenia & I B, 2 & I B, 9 & I B, 11 \\
& I C, 8 & I C, 30 & I C, 38
\end{tabular}

Paranoid Schizophrenia

$\begin{array}{lll}\text { I B, } 2 & \text { I B, } 2 & \text { I B, } 4 \\ \text { I C, } 11 & \text { I C, } 6 & \text { I C, } 17\end{array}$

Simple Schizophrenia

I $A, 3$

I $A, 3$

I C, 3

I C, 3

Manic Depressive I1lness

I B, 2

I $C, 2$

I C, I

I B, 2

I $C, 3$

Schizoaffective Disorder

$\begin{array}{lllll}\text { I B, } 1 & \text { I B, } 2 & \text { I B, } 3 \\ \text { I C, } 1 & \text { I C, } & 1 & \text { I C, } 2\end{array}$

Schizoid Personality

I C, I

I $\mathrm{C}, \mathrm{I}$

Paranoid Personality with Alcoholism

I C, 1

I $\mathrm{C}, \mathrm{I}$

Depressive Neurosis

I C, 5

I C, 5

Hysterical Neurosis

I C, 1

I C, 1 


\section{RESULTS/INTERVIEWED SAMPLE}

of the total sample, thirty-six individuals were interviewed. These thirty-six subjects comprise the interviewed sample.

The interviewed sample $(\mathrm{N}=36)$ was divided into two groups, i.e., Umatilla County and non-Umatilla counties (Hood River, Wasco, Union, Malheur, Baker, Wallowa, Wheeler, Gilliam, Sherman, Grant, Morrow, Harney). Within Umatilla County there were fourteen individuals interviewed (39\%) and within the remaining counties there were twentytwo $(61 \%)$ interviewed.

The average age of the subjects interviewed in the Umatilla group was 43.7, the standard deviation was 16.93. The average age of those interviewed in the non-Umatilla group was 41.9 , the standard deviation was 15.25. The average age of the total group was 42.6, the standard deviation was 15.80 . 
Demographic Information:

TABLE VIII

UMATILLA/NON-UMATILLA BY AGE

\begin{tabular}{|c|c|c|c|c|c|c|c|c|c|c|c|}
\hline \multirow{2}{*}{\multicolumn{2}{|c|}{$\bar{x}=43.7$}} & & & \multicolumn{4}{|c|}{$\begin{array}{c}\text { Age } \\
\text { Non-Umatilla }\end{array}$} & \multicolumn{4}{|c|}{$\begin{array}{l}\text { Age } \\
\text { Total }\end{array}$} \\
\hline & & $S D=16$ & & $\bar{x}=4$ & & $S D=1$ & & $\bar{x}=42$ & & $S D=7$ & \\
\hline $\begin{array}{c}\text { Age } \\
18-22 \\
23-27 \\
28-32 \\
33-37 \\
38-42 \\
43-47 \\
48-52\end{array}$ & $\begin{array}{l}f \\
1 \\
3 \\
1\end{array}$ & $\begin{array}{c}\text { Age } \\
53-57 \\
58-62 \\
63-67 \\
68-72 \\
73-77 \\
78-82\end{array}$ & $\begin{array}{l}f \\
1 \\
4 \\
1\end{array}$ & $\begin{array}{c}\text { Age } \\
18-22 \\
23-27 \\
28-32 \\
33-37 \\
38-42 \\
43-47 \\
48-52\end{array}$ & $\begin{array}{l}f \\
1 \\
2 \\
7 \\
1\end{array}$ & $\begin{array}{c}\text { Age } \\
53-57 \\
58-62 \\
63-67 \\
68-72 \\
73-77 \\
78-82\end{array}$ & $\begin{array}{l}f \\
2 \\
4 \\
1\end{array}$ & $\begin{array}{c}\text { Age } \\
18-22 \\
23-27 \\
28-32 \\
33-37 \\
38-42 \\
43-47 \\
48-52\end{array}$ & $\begin{array}{l}f \\
2 \\
5 \\
8 \\
1 \\
1 \\
2 \\
4\end{array}$ & $\begin{array}{c}\text { Age } \\
53-57 \\
58-62 \\
63-67 \\
68-72 \\
73-77 \\
78-82\end{array}$ & $\begin{array}{l}f \\
3 \\
8 \\
2\end{array}$ \\
\hline
\end{tabular}

Fifteen subjects (42\%) were male and twenty-one (.58\%) were female.

TABLE IX

UMATILLA/NON-UMATILLA BY SEX

Umatilla Non-Umatilla Total

\begin{tabular}{cccccc}
\hline & & & $f$ & $\%$ \\
Sex & Male & $f$ & 8 & 15 & $42 \%$ \\
& Female & 7 & 14 & 21 & $58 \%$ \\
\hline
\end{tabular}

Most had no dependents (thirty or $83 \%$ ) and only six participants $(17 \%)$ had one or more. 
TABLE $X$

NUMBER OF DEPENDENTS

\begin{tabular}{lcccc}
\hline & & Umatilla & Non-Umatilla & Total \\
\hline \multirow{3}{*}{ * Dependents } & & $f$ & $f$ & $f$ \\
& 0 & 11 & 19 & 30 \\
& 1 & 1 & 1 & 2 \\
& 2 & 1 & 1 & 2 \\
& 3 & 1 & 1 & 2 \\
\hline
\end{tabular}

The majority were either divorced (fourteen or 39\%) or single (seventeen or $47 \%$ ). Only four participants $(11 \%)$ were married at the time of the interview.

TABLE XI

MARITAL STATUS

Umatilla Non-Umatilla Total

\begin{tabular}{llrrrr}
\hline & & & $f$ & $\%$ \\
Marital & Married & 1 & 3 & 4 & $11 \%$ \\
Status & Single & 6 & 11 & 17 & $47 \%$ \\
& Divorced & 8 & 6 & 14 & $39 \%$ \\
& Separated & & 1 & 1 & \\
& Widowed & & & & \\
\hline
\end{tabular}

*Dependents - Children only. 
A11 were of white ethnicity.

TABLE XII

ETHNIC GROUP

\begin{tabular}{llccc}
\hline & & Umatilla & Non-Umatilla & Total \\
\hline \multirow{2}{*}{ Race } & $f$ & $f$ & $f$ \\
& $\begin{array}{l}\text { Black } \\
\text { White } \\
\text { American Indian } \\
\text { Hispanic }\end{array}$ & 14 & 22 & 36 \\
\hline
\end{tabular}

Twenty-seven individuals (75\%) had no high school diploma and twenty (56\%) had an education level of 10-12 years. Nine (25\%) reported 12 or more years of schooling.

TABLE XIII

EDUCATIONAL LEVEL

Umatilla Non-Umatilla Total

\begin{tabular}{ccrrr}
\hline & $f$ & $f$ & $f$ \\
Education & $1-6$ & & 1 & 1 \\
& $7-9$ & 4 & 2 & 6 \\
$10-12$ & 10 & 10 & 20 \\
$12+$ & & 9 & 9 \\
& & & \\
\hline
\end{tabular}

As can be seen, the majority of the sample (70\%) were at or near the poverty level. See Table XIV. 
TABLE XIV

INCOME LEVEL

\section{Umatilla Non-Umatilla Total}

\begin{tabular}{crrrrr}
\hline & $f$ & $f$ & $f$ & $\%$ \\
Income & $0-2,999$ & 5 & 9 & 14 & $39 \%$ \\
& $3,000-3,999$ & 5 & 6 & 11 & $31 \%$ \\
$4,000-4,999$ & 1 & 3 & 4 & $11 \%$ \\
$5,000-5,999$ & 1 & 2 & 3 & $8 \%$ \\
$6,000-6,999$ & 1 & 2 & 3 & $8 \%$ \\
$7,000-7,999$ & & & & \\
$8,000-8,999$ & & 1 & 1 & $3 \%$ \\
$9,000-9,999$ & 1 & & & \\
$10,000-10,999$ & & & & \\
$11,000-14,999$ & & & & \\
$15,000+$ & & & & \\
\hline
\end{tabular}

The most typical source of income was self-employed or a combination of social security and SSI. Fifteen individuals (42\%) combined their own earnings with other sources. Five (14\%) relied on some supplement from their family and nineteen subjects (53\%) relied solely on social service funds for their income. 
TABLE XV

INCOME SOURCE

\section{Umatilla Non-Umatilla Total}

Income Self

Source Family

Welfare

Social Security/SSI

Veterans

Self and Family

Self and Social Security

Self and Welfare

Family and Social Security

Social Security and Welfare 6

Welfare, Social Security and Veterans f

3

1

1

2

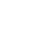

1

$\begin{array}{rrr}f & f & \% \\ 6 & 9 & 25 \% \\ 1 & 1 & 3 \% \\ 1 & 1 & 3 \% \\ 8 & 9 & 25 \% \\ 1 & 1 & 3 \% \\ 2 & 3 & 8 \% \\ 1 & 1 & 3 \% \\ 1 & 2 & 6 \% \\ 1 & 1 & 3 \% \\ 1 & 7 & 19 \%\end{array}$

$13 \%$

of the thirty-six subjects interviewed, twenty-three (64\%) were either living in a single-family dwelling or an apartment. Only ten (28\%) were residing with relatives. Twenty-four (67\%) lived with other individuals. Twelve (33\%) lived alone.

*Due to rounding error. 
TABLE XVI

TYPE OF RESIDENCE

Umatilla Non-Umatilla Total

$\begin{array}{lllrrr} & & f & f & f & \% \\ \text { Type of } & \text { Single Family Dwelling } & 3 & 10 & 13 & 36 \% \\ \text { Residence } & \text { Apartment } & 4 & 6 & 10 & 28 \% \\ & \text { Hotel } & 1 & & 1 & 3 \%\end{array}$

Room and Board

Intermediate Care Facility

Coop. House/Apartment

2

$26 \%$

Coop. House Supervised

Shelter Group Home

(A11 in one group home)

Skilled Nursing Home

Trans. Group Home

2

$6 \quad 17 \%$

$26 \%$

$26 \%$

$102 \% *$

\section{TABLE XVII}

LIVING ARRANGEMENT

Umatilia Non-Umatilla Total

\begin{tabular}{|c|c|c|c|c|c|}
\hline $\begin{array}{l}\text { Living } \\
\text { Arrange- } \\
\text { ments }\end{array}$ & $\begin{array}{l}\text { Living Alone } \\
\text { Living with Others } \\
\text { Living with Family }\end{array}$ & $\begin{array}{l}f \\
5 \\
6 \\
3\end{array}$ & $\begin{array}{l}f \\
7 \\
8 \\
7\end{array}$ & $\begin{array}{r}f \\
12 \\
14 \\
10\end{array}$ & $\begin{array}{c}\% \\
33 \% \\
39 \% \\
28 \%\end{array}$ \\
\hline
\end{tabular}

of our sample, only five individuals (14\%) lived in towns of

1,000 population or less. However, it must be mentioned that the

*Due to rounding error. 
largest city in the region sampled (Pendleton) has a total population of 14,650 .

TABLE XVIII

PLACE OF RESIDENCE

Umatilla Non-Umatilla Total

Place of

Residence

$$
\begin{aligned}
& 0-250 \\
& 251-500 \\
& 501-1,000 \\
& 1,001-2,000 \\
& 2,000+
\end{aligned}
$$

$f$ $\mathrm{f}$

3

1

17 $f$

1

3

14
1

1

31

Diagnosis:

In Group I of the interviewed participants, thirteen participants (36\%) were diagnosed chronic undifferentiated schizophrenic and thirteen participants (36\%) diagnosed paranoid schizophrenic. Thus, combined accounted for (72\%) of the individuals interviewed. Thirtythree individuals (92\%) were identified as either chronic undifferentiated schizophrenic, paranoid schizophrenic, schizophrenic, or manic depressive. The predominant diagnosis shifted from chronic undifferentiated schizophrenia in Umatilla County to paranoid schizophrenia in the remaining counties. 
TABLE XIX

INTERVIEWED SUBJECTS BY DIAGNOSIS

Diagnos is

Umatilla

Non-Umatilla

Male Female Total 1 Male Female Total 2

\begin{tabular}{|c|c|c|c|c|c|c|c|c|}
\hline & $f$ & $f$ & $f$ & $\%$ & $f$ & $f$ & $f$ & $\%$ \\
\hline \multicolumn{9}{|l|}{ Chronic Undifferentiated } \\
\hline Schizophrenia & 3 & 7 & 10 & $71 \%$ & 0 & 3 & 3 & $14 \%$ \\
\hline Paranoid Schizophrenia & 2 & 1 & 3 & $22 \%$ & 6 & 4 & 10 & $45 \%$ \\
\hline Simple Schizophrenia & 0 & 0 & 0 & 0 & 0 & 3 & 3 & $14 \%$ \\
\hline Manic Depressive Illness & 1 & 0 & 1 & $7 \%$ & 2 & 1 & 3 & $14 \%$ \\
\hline Schizoaffective Disorder & 0 & 0 & 0 & 0 & 0 & 2 & 2 & $9 \%$ \\
\hline Schizoid Personality & 0 & 0 & 0 & 0 & 0 & 0 & 0 & 0 \\
\hline $\begin{array}{l}\text { Paranoid Personality with } \\
\text { Alcoholism }\end{array}$ & 0 & 0 & 0 & 0 & 1 & 0 & 1 & $5 \%$ \\
\hline Depressive Neurosis/Hys- & & & & & & & & \\
\hline terical Neurosis & 0 & 0 & 0 & 0 & 0 & 0 & 0 & 0 \\
\hline Total & $\overline{6}$ & $\overline{8}$ & 14 & $100 \%$ & $\overline{9}$ & $\overline{13}$ & $\overline{22}$ & $101 \% *$ \\
\hline
\end{tabular}

Diagnosis Total

Male

Female

Tota 1

Chronic Undifferentiated Schizophrenia

Paranoid Schizophrenia

Simple Schizophrenia

Manic Depressive Illness

Schizoaffective Disorder

Schizoid Personality

Paranoid Personality with Alcoholism

Depressive Neurosis/Hysterical Neurosis

Total

\begin{tabular}{rrr}
3 & 10 & 13 \\
8 & 5 & 13 \\
0 & 3 & 3 \\
3 & 1 & 4 \\
0 & 2 & 2 \\
0 & 0 & 0 \\
1 & 0 & 1 \\
0 & 0 & 0 \\
\hline 15 & 21 & 36
\end{tabular}

*Due to rounding error 
Transportation Data:

of the three social services surveyed, the community mental health centers were the most often used by the chronically mentally 111 subjects. Thirty-four or $94 \%$ of the interviewees said that they used the community mental health center. Nine or $25 \%$ of the subjects interviewed said they used Adult \& Family Services and only 2 or $6 \%$ of the subjects said that they had used Vocational Rehabilitation.

\section{TABLE XX}

CLIENT REPORTED USE OF SOCIAL SERVICES

1. Community Mental Health Center

2. Adult \& Family Services

3. Vocational Rehabilitation

Umatilla -13
Non-Umatilla -21
Total -34
Umatilla -7
Non-Umatilla - 2
Total - 9
Umatilla - 0
Non-Umatilla -2
Total -2

Seven or $50 \%$ of the Umatilla group used the Community Mental Health Center (CMHC) once per week. Five or $23 \%$ of the non-Umatilla group used the CMHC once per week. The non-Umatilla group tended to use the CMHC less frequently than the Umatilla group and more of the non-Umatilla group (32\%) used the CMHC on a crisis basis than the Umatilia group $(21 \%)$. 
TABLE XXI

FREQUENCY OF USE OF COMMUNITY MENTAL

HEALTH CENTERS PER MONTH

1 per month

2 per month

3 per month

4 per month

Crisis onty

Service not used

$$
\begin{array}{r}
\text { Umatilla }-1 \\
\text { Non-Umatilla }-3 \\
\text { Total }-4
\end{array}
$$
Umatilla - 2 Non-Umati11a - 6 Total - 8

Umatilia - 0 Non-Umatilla - 0 Total - 0 Umatilla - 7 Non-Umatilla - 5 Tota $1-12$

Umatilla - 3 Non-Umatilla - 7

Tota $1-10$

Umatilla - 1 Non-Umatilla - 1

Only three subjects in total reported health as a limiting factor with regard to their transportation to CMHCs. 
HEALTH LIMITATIONS OF CLIENTS AS THEY AFFECT

TRANSPORTATION TO CMHC SERVICES

1. Vision

2. Hearing

3. Other
Umatilia - 2

Non-Umatilla - 0

Total - 2

Umatilla - 2

Non-Umatilla - 0

Total - 2

Umatilla - 0

Non-Umatilla - 1

Total - 1

All of the subjects who owned a car used it for transportation to the CMHCs. The most common mode of transportation to the CMHCs was in someone else's car. The next most common mode of transportation was to walk. The CMHCs provided about $22 \%$ of the transportation needs of the total interviewed sample. 
MODE OF TRANSPORTATION USED BY CLIENT TO RECEIVE MENTAL HEALTH SERVICES

1. Self Car

2. Wa $7 \mathrm{k}$

3. Bicycle

4. Hitchhike

5. Taxi

6. Agency

7. Other Car

$$
\begin{array}{r}
\text { Umatilla }-3 \\
\text { Non-Umatilla }-10 \\
\text { Total }-13 \\
\\
\text { Umatilla }-5 \\
\text { Non-Umatilla }-9 \\
\text { Total }-14 \\
\\
\text { Umatilla }-0 \\
\text { Non-Umatilla }-3 \\
\text { Total }-3
\end{array}
$$

$$
\text { Umatilla - } 1
$$$$
\text { Non-Umatilia - } 1
$$$$
\text { Total - } 2
$$

Umatilla - 3 Non-Umatilia - 0

Total - 3

$$
\begin{array}{r}
\text { Umatilla }-4 \\
\text { Non-Umatilla }-4 \\
\text { Total }-8 \\
\text { Umatilla }-9 \\
\text { Non-Umatilla }-8 \\
\text { Total }-17
\end{array}
$$

Ten or $45 \%$ of the subjects in the non-Umatilla group reported that they had their own car for transportation to the CMHC while only three or $21 \%$ of the Umatilla group reported that they had their own car. Fourteen or $64 \%$ of the non-Umati1la group said that they were aware that the CMHC would provide transportation. Five or $36 \%$ of the Umatilla group reported that the CMHC would provide transportation. 
TABLE XXIV

MODE OF TRANSPORTATION TO

MENTAL HEALTH SERVICES THAT CLIENTS WERE AWARE OF

1. Staff Car

2. Bus

3. Taxi

4. Bicycle

5. Agency

6. Other Car
Umatilla - 3

Non-Umatilla - 10

Total - 13

Umatilia - 0

Non-Umatilla - 0

Total - 0

Umatilla - 3

Non-Umatilla - 2

Total - 5

Umatilla -0
Non-Umatilla -3
Total -3

Umatilla -5

Non-Umati1la - 14

Total - 19

Umatil1a - 9

Non-Umati11a - 10

Total -19

Eleven or $50 \%$ of the non-Umatilla group reported that snow and ice on roads was a limiting factor with regard to transportation to the CMHCs in the winter months. The Umatilla group did not report any of the three geographic or climatic factors listed as problems which they encountered with regard to transportation to the CMHCS. All of the subjects interviewed lived on or near paved roads. 
TABLE XXV

GEOGRAPHIC \& CLIMATIC BARRIERS

WITH REGARD TO TRANSPORTATION

TO COMMUNITY MENTAL HEALTH SERVICES

1. Passes Closed

$$
\begin{array}{r}
\text { Umatilla }-0 \\
\text { Non-Umatilla }-1 \\
\text { Total }-1 \\
\\
\text { Umatilla }-0 \\
\text { Non-Umatilla }-11 \\
\text { Total }-11 \\
\text { Umatilla }-0 \\
\text { Non-Umatilla }-0 \\
\text { Total }-0
\end{array}
$$

2. Snow \& Ice

3. Gravel \& Dirt Roads

The average distance traveled for mental health service in the Umatilla group was 4.77 miles, and the standard deviation for this group was 7.46. One subject in the Umatilla group traveled thirty miles to receive service.

The average distance traveled for service in the non-Umatilla group was 4.11 miles and the standard deviation was 8.62. There was one subject in this group who traveled twenty-eight miles and one who traveled thirty miles for mental health service.

The average distance traveled for the total group was 4.38 miles. 
TABLE XXVI

DISTANCE TRAVELED FOR MENTAL HEALTH

SERVICES IN MILES

1. Umatilla

$\bar{x}=4.77$

$S D=7.46$

2. Non-Umatilla

$\bar{x}=4.11$

$S D=8.62$

3. Total

$\bar{x}=4.38$

$\mathrm{SD}=8.04$

Two subjects reported a free floating fear or generalized anxiety with regard to leaving their home which negatively affected their access to the CMHC.

Five subjects reported a specific fear of motor vehicles.

TABLE XXVII

PSYCHOLOGICAL BARRIERS OF CLIENT WITH

REGARD TO RECEIPT OF MENTAL. HEALTH

SERVICES

1. Free Floating Fear

3. 0 ther

$$
\begin{array}{r}
\text { Umatilla }-0 \\
\text { Non-Umatilla }-2 \\
\text { Total }-2 \\
\\
\text { Umatilla }-2 \\
\text { Non-Umatilla }-3 \\
\text { Total }-5 \\
\text { Umatilla }-0 \\
\text { Non-Umatilla }-0 \\
\text { Total }-0
\end{array}
$$


Criteria:

Of the CSP criteria, category IC identified twenty-three or $64 \%$ of the interviewed sample. Under category II, II A (unemployed, 1imited work skills, or poor work history) was most often checked. Thirtythree participants (92\%) were included in this category. These categories did not significantly differ between the Umatilla or Non-Umatilla groups.

Only three $(20 \%)$ of the total interviewed male population of 15 were identified by items I A or I B of the CSP criteria, while ten $(48 \%)$ of the total interviewed female population of 21 were identified by using Items I A or I B of the criteria. 


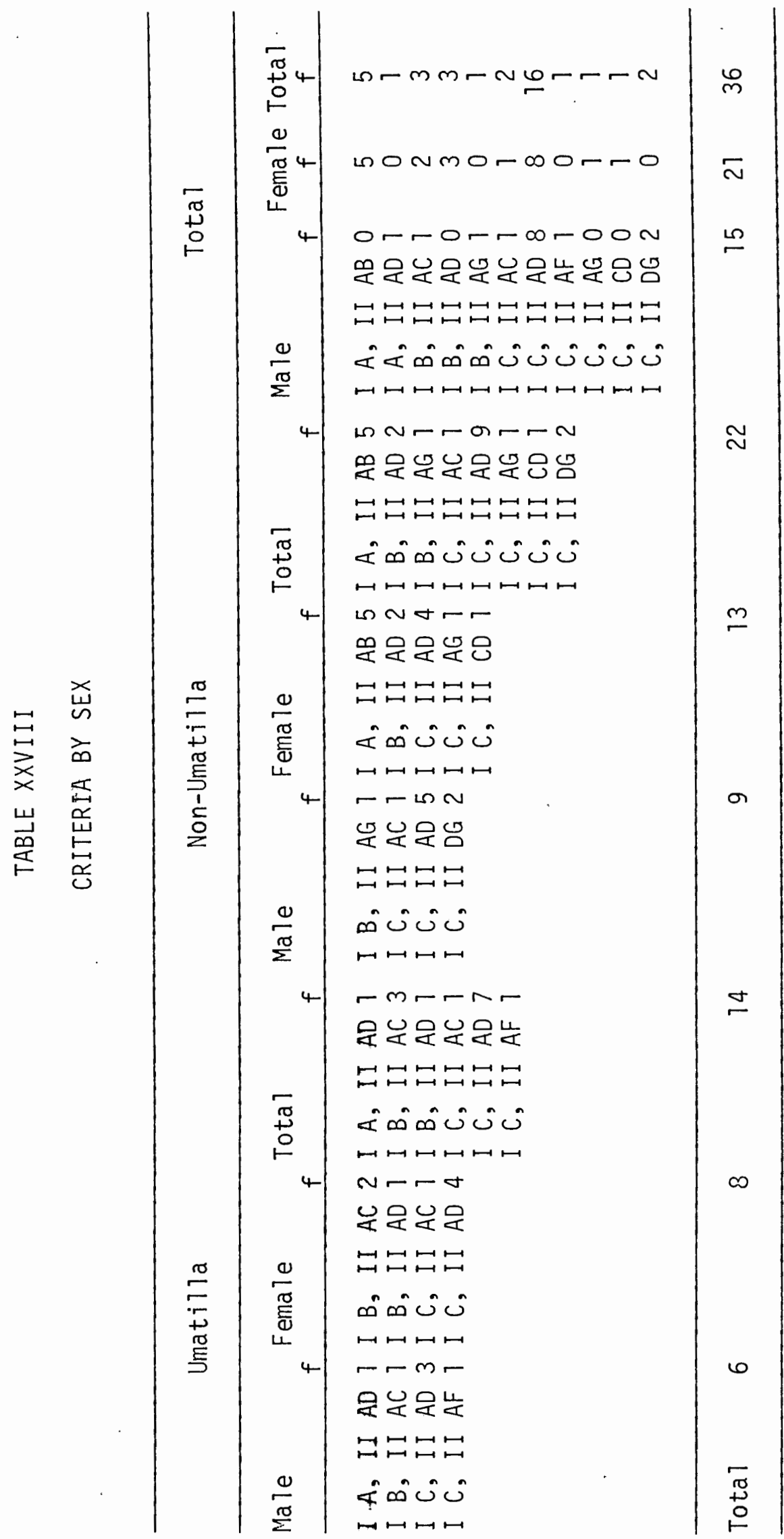




\section{DISCUSSION OF RESULTS}

The total sample of the chronically mentally $i 11$ population was fairly homogeneous. The sample included forty-eight men and forty-nine women. The males, on the average, were 7.1 years younger than the females with the average age for the total group 36.4. The ages ranged from eighteen to sixty-seven with ages clustering between twenty and thirty-five. The vast majority of the sample were of white ethnicity which is congruent with the general population in Eastern Oregon. The majority of the clients were diagnosed as having a psychotic dysfunction and given the nature of psychiatric illnesses, this would seem logical. In general, the psychotic dysfunctions are much more debilitating than the other psychiatric disorders and tend to be recurrent and have a progressively deteriorating course. The exception to this is manic depression illness, which, if treated properly, will usually be recurrent but without extreme deterioration.

In the total sample, there were few noticeable differences between the Umatilia and non-Umatilla group. One exception was a slightly lower average age for the non-Umatilla group.

The interviewed sample was again quite nomogeneous. They were all of white ethnicity and of a similar socio-economic background with $70 \%$ of them earning less than $\$ 5,000$ per year. The majority of this group received some sort of financial support either from welfare, social security, SSI, Veterans Administration or family. This population had limited interpersonal support systems as evidenced by the 
fact that $83 \%$ had no dependents, $4 \%$ were currently married and $28 \%$ were living with family. Seventy-five percent of the interviewed sample had not finished high school, the majority dropping out of school sometime between their sophomore and senior year. Ninety-two percent of this group were diagnosed as having a psychotic dysfunction which again fits with the general picture of the chronically mentally ill population.

The average age of the interviewed sample was 6.2 years older than the average age of the total sample and this difference was quite similar for both the Umatilla and non-Umatilla groups. This difference in age may again be accounted for by assuming that the interviewed sample were more likely to be an older, more stable population, since the primary factor in determining their inclusion in the interviewed sample was their availability. It is likely that because of this factor our data is somewhat biased, but to what extent it is impossible to determine. Then again, because of this fact, it may be more descriptive of the population who the community mental health centers regularly serve.

The ratio of males to females was also different in the two samples. In the total sample, the ratio was approximately $1: 1$, while in the interviewed sample, the ration was almost $3: 2$ in favor of the females. This is probably again related to the stability of the population, i.e., males are more likely to lead a transient existence due to our cultural norms with regard to mobility.

The interviewed sample, for the most part, lived in communities of more than 2,000 people. In the majority of cases, they lived in or near a town which offered community mental health services. The 
overall average distance traveled for mental services was 4.38 miles, but for upwards of $90 \%$ of this sample, the average was close to 2.5 miles. This factor, coupled with readily available means of transportation, indicate fairly easy access to the community mental health centers for the majority of the interviewed subjects.

There were some basic differences regarding means of transportation used between the Umatilla and non-Umatilia groups. Only three of the fourteen subjects interviewed in Umatilla County had their own cars, while ten of the twenty-two subjects in the non-Umatilla group owned cars. In regard to the transportation modes which the clients were aware of (see Table XXIII) there was substantial difference between awareness of availability in the Umatilla and non-Umatilla groups. In the Umatilla group, there were eight reports of either staff or agency cars or both, while in the non-Umatilla group, there were iwenty-four reports.

The clients' health and/or fear of using transportation had only a limited effect on the clients' access to the community mental health centers. The climate and road conditions were a factor in access to service for approximately $30 \%$ of the interviewed sample and these were a11 in the non-Umatilla group.

In examining the differences between the two groups in the interviewed sample with regard to frequency of use of the community mental health centers, two patterns emerge. Although in both groups the $c$ lients used the community mental health centers with some regularity, within the Umatilla group, seven or $50 \%$ of the sample used the community mental health centers on a weekly basis, while in the non- 
Umatilla group, the frequency of use was less and tended towards a more crisis orientation and monthly or bi-monthly visits. 


\section{IMPLICATIONS AND CONCLUSIONS}

In general, our data indicates that transportation is not an overwhelming service delivery problem. It appeared that adequate transportation to mental health services was usually provided by mental health agency outreach, family, natural networks, auxillary services such as senior citizens, or other public or private organizations. The majority of individuals sampled in all communities lived in close proximity to mental health services and usualiy found their access to the services to pose no major problem. However, it must be pointed out that this conclusion was founded on the results of the interview data which contained approximately $50 \%$ of the identified CMI total sample. Thus, it is possible that transportation for service may have been an issue for the non-interviewed sample. Although it was the concensus of our informal discussions with clinic staff that this was generally not the case.

The exception to this observation, i.e., generally adequate available transportation to mental health services, was found in Umatilla County and more specifically in Pendleton. Umatilla County apparently has the greater problem, due to the EOSH being located there and the large number of releasees electing to remain in Pendleton. On the average, the sampled population in Pendleton lived 4.8 miles from mental health services and, at time, both clients and staff perceived that there was difficulty in getting to the clinic or obtaining outreach. Pendleton does have an active taxi service, but costs are 
prohibitive to the CMI population due to limited incomes. The only bus service available in Eastern Oregon is the interstate system, with no other county or town services available. Umatilla County does have a satellite office in Hermiston which provides for the needs of the people in that outlying area. However, some clients found it difficult to obtain services in the Milton-Freewater area. Our findings were congruent with CSP findings in Umatilla County. ${ }^{9}$ Also noted in our research data, the majority of people released from EOSH, i.e., 58\%, settled in Umatilla County. This data is significant, as Umatilla County appears to lack in manpower to successfully monitor, track, and provide necessary outreach to the CMI population. Though Umatilla County has earnest concern for the CMI, it appeared that follow-up was most difficult due to the large quantity of CMI's residing there.

From our efforts to identify the CMI population of the EOSH and track them back to the community, it was found that approximately $50 \%$ of the individuals discharged to the catchment area were not available for interview data collection. This was due to two main factors. First, a large portion of the individuals were apparently of a transient population and, thus, had no "roots" in any of the catchment area communities. Though often officially discharged back to the community of their initial referral, these individuals quickly disappeared from community view and were assumed by the MHC staff and community members to have "moved on". Second, the remaining individuals lost from the sample were known to the CMHCs and community, but had moved from the catchment area. In this group, individuals apparently moved for two main reasons. A portion moved to an area where significant relatives 
were located or had relocated. The others moved primarily to be involved in some specific mental health service such as a group home or day treatment program.

In review of the demographic data, we found the CMI population sampled was essentially all of white ethnicity. However, some of the population we could not find were Spanish American and, according to neighbors, were back in the migrant stream. It was also noted that when a hospital or MHC was located on interstate highway systems, they encounter more migrant and transient individuals.

Another issue we found was that the majority of the sampled population was existing on incomes at or near the poverty level. It appeared obvious that functioning in the community was related to level of income. We know that the appropriation of income to these individuals is a rather global issue and based on many different rules and regulations.

It was the researchers' conclusion that new means of supplementing income could be investigated and developed. For example, one area where income could at least be stretched is through the continued development of shared housing examplified by the LINC program. This also provides better and more consistent support systems that, in part, addresses the needs of these individuals.

In regards to manpower, it would seem efficacious that more manpower funds be directed at outreach in the Umatilia County area where the greatest bulk of the population resides.

With additional manpower, natural support systems could be developed to assist people living by themselves in the community. As 
can be seen by our data, a large portion of our total sampled population was living alone or had no primary relationships which could mean problems in adapting and maintaining support systems. Support systems become a critical issue in Umatilla County because of the large number of CMI population living there.

Rural and small towns appeared ripe for the implementation of support systems, as evidenced by the success of the LINC Program in Pendleton and the Columbia Gorge Rehabilitation Center in Hood River. Also, by increasing natural systems in conjunction with additional professional manpower, the clinician may have the opportunity to interface with their clients in an everyday role as opposed to the traditional MHC situation. First-hand observations appear important for the mental health worker in determining community success of a particular client. By developing outreach and support systems, the clinician can utilize other valuable tools, i.e., family reports, friends of the client and other clients in focusing on the needs of each client. It would also be useful to tie into existing transportation systems such as those systems which are already established for the aged or other handicapped individuals. This type of flexibility was seen in a few of the counties in the Eastern Oregon Comprehensive Community Mental Health Center Catchment area.

In developing natural systems in a community, it is apparent that means are needed outside the mental health clinic itself. One of the first steps in developing community resources is to utilize existing strengths of the community, such as churches, fraternal organizations, etc. The use of volunteer services could also be further 
developed. We found each community to be unique in the possible resources available. Also development of volunteer resources may enhance community responsibility to the CMI population, which is one of the main principles of the deinstitutionalization movement. This may, in turn, develop community spirit and cohesiveness in the assistance and integration of the CMI population. Also community involvement serves to lessen the stigma attached to the CMI population and further their acceptance with the community on a more healthful level. Anonymity is almost nonexistent in small communities which can further enhance in the understanding of these individuals. In addition, all this appears to be congruent with the sociology of rurat life.

In developing staff, it appears important to either select and/or train them for small town work, and small town living. Small clinics in particularly isolated areas tend to have a higher turnover rate than Targe urban areas due to a large extent to a lack of knowledge and experience of the subleties of smal.1 town living.

This leads to another issue in the rural community service delivery, that of community acceptance of both the worker and the client. More important seems the acceptance of the client by the community which directly or indirectly sent the person to the hospital. From personal interviews, it was our perception that acceptance of the CMI was more readily available in small towns.

Informal information systems appeared to be more viable in smaller towns, than in a larger town such as Pendleton. This, in turn, get back to the need for more available manpower in Umatilla where there is a larger concentration of CMI population. 
One area of service utilization that could be expanded is consultation to care centers and nursing homes by mental health clinics. In many of these care centers and nursing homes, we found the staff perplexed at some of the behavior the CMI clients exhibited and confused about ways of effectively dealing with the many problems. It is not a question of poor care, but one of a lack of knowledge about the CMI.

In general, we found that the professional staff of the Eastern Oregon Comprehensive Community Mental Health Programs to be quite knowledgeable and skilled in the deinsitutionalization process, in community mental health ideology, and maintained a high degree of active professionalism. The workers appeared naturally supportive and extremely aware of the CMI's overall needs, as well as the deficiencies present in the community and agency resources.

Our observations suggest a situation unique to rural centers, which in the future could lead to more and better services. Strong community involvement is essential in the development of support systems and the LINC program clearly utilizes this involvement. A1though there was talk of pending funding cuts, we noted the zeal that each center possessed in establishing and maintaining service delivery in their respective areas.

In summary, the survey revealed that transportation to and from mental health clinics, although a concern for some, was not an overriding issue for the sampled CMI population in the Eastern Oregon Comprehensive Community Mental Health Center Catchment area. Most of the CMI clients can find transportation to the mental health clinics and 
utilize these services as indicated by the fact that $67 \%$ of the CMI population we interviewed used them regularly.

However, from interviews with both clinic staff and CMI individuals, it was the researchers' definite impression that transportation for daily living, i.e., shopping, socialization, recreation, etc., was a definite problem and often exasperated their social isolation.

Additionally, it was our observation that poverty, lack of education and unemployment are such dominant characteristics of this population that positive therapeutic impact by the community mental health clinics alone is a most difficult and possibly an impossible task. Even though the mental health services are accessible to the clients, the clinic staff can often do little more than apply "band-aid" approach due to the existing socio-economical pressures which dominate the lives of the chronically mentally ill clients. With the clients we encountered, their poverty seemed to be a generational problem and not singly a symptom or product of their illness. Although we realize that money will not solve all of the problems of these individuals, it seems apparent that improved economic conditions would make their problems more manageable and also make the clinic staff perhaps more optimistic about their ability to provide substantial help.

Not only is the chronically mentally ill population beset with economic problems, but so are the clinics. For instance, in a few of the mental health clinics that we interviewed, outreach mileage was either partially or fully paid for by individual staff members due to the limited funding of the agencies. However, this in one way exemplifies the motivation of some of the clinic staff in their efforts 
to establish and maintain a viable service.

Typical1y, money appears to be a major component in many of the social service problems. We suggest that if the federal government has a sincere concern for the chronically mentally 111 population, they will demonstrate this by providing adequate funding incentive for the community mental health clinics and other programs. In addition, consideration of overhauling the welfare and social security benefits process in regards to this population would be of immense benefit. This seems specially important in regards to this population's realistic fear of losing financial aid while attempting to seek out and maintain either full or partial self-employment. 


\section{FOOTNOTES}

1L. L. Bachrach, Deinstitutionalization: An Analytical Review and Sociological Perspective, Mental Health Series D., No. 4, NIMH, Rockville, Maryland, 1976

${ }^{2}$ L. L. Bachrach, "Deinstitutionalization of Mental Health Services in Rural Areas," Hospital and Community Psychiatry, Vol. 78, No. 9, September 1977, p. 669-72.

${ }^{3}$ Jules Cohen, "The Effect of Reliance on Use of Outpatient Service in a Rural Mental Health Center," Hospital and Community Psychiatry, March 1972. p. 27-28.

$4 \mathrm{~J}$. Stackhouse, Characteristics and Community Adjustment of Former EOSH and Training Center Patients Who Evidence Chronic M \& $E$ Disturbances, Masters Thesis, University of Washington, 1977.

${ }^{5}$ Susan J. We1sh, Debbie Klein-Skei, Community Support Systems for the Chronically Mentally 117: A Report of Findings in Umati7la County, August, 1978. p. 28-30.

${ }^{6}$ Stein Springer, "Factors in Utilization of Mental Health Clinics and State Hospitals" Community Hospital and Psychiatry, May 1977, pp. 379-81.

${ }^{7}$ R. D. Morrison, Christopher Newport College, Newport News, Virginia, January 1976, p. 671.

${ }^{8} \mathrm{M}$ Mazu, People and Predicaments, (Cambridge, Mass: Harvard Press) 1976, p. 215.

9 op. cit. 2, p. 669.

10 op. cit. 5, p. 28-30. 


\section{BIBLIOGRAPHY}

Agel, J. The Radical Therapist. New York: Ballatine Books, 1971.

Bachrach, L. L. "A Survey of Rural Community Mental Health Needs and Resources," Hospital and Community Psychiatry, December, 1975.

Buxton, E. "Delivering Social Services in Rural Areas," Public Welfare, Winter, 1973.

Chesteen, W. "Georgraphic Mobility and Mental Disroder," Hospital and Community Psychiatry, January, 1970.

Clark, D. Revised Guide to the Rural Development Act of 1972, Washington, D. C.: U. S. Government Printing Office, 1975.

Cohen, J. "The Effect of Distance on Use of Outpatient Services in a Rural Mental Health Center," Hospital and Community Psychiatry, March, 1972.

Conference Report. "Issues in the Delivery of Rural Mental Health Services," Hospital and Community Psychiatry, September, 1977.

Daniels, D. N. "The Community Mental Health Center in the Rural Area," American Journal of Psychiatry, December, 1967.

Dutton, E. P., et. a1. A Specialist-Generalist Model of Social Work Practice for Contemporary Rural America, University of Kansas, School of Social Work, February, 1977.

Edgerton, J. W. and Bentz, W. K. "Attitudes and Opinions of Rural People About Mental Illness and. Program Services," American Journal of Public Health, March, 1960.

Eisdorfer, C., et. al. "Principles of Community Mental Health in a Rural Setting: The Halifax County Program," Community Mental Health Journal, Apri1, 1968.

Ganser, L. J., et. al. "A Mental Health Equcation Program in a Rural Area," Hospital and Community Psychiatry, February, 1976.

Gertz, B., et. al. "A Survey of Rural Community Mental Health Needs and Resources," Hospital and Community Psychiatry, December, 1975.

Ginsberg, L. H. "An Overview of Social Work Education for Rural Areas," in Social Work in Rural Communities. Leon H. Ginsberg, (ed.) New York: Council on Social Work Education, 1976. 
Gurian, H. "A Decade in Rural Psychiatry," Hospital and Community Psychiatry, February, 1971.

Halpern, H. and Love, Ronald. "Initiating Community Consultation in Rural Areas," Hospital and Community Psychiatry, September, 1971.

Hoag, Laurence. "Transportation Issues of the Handicapped," Human Factor, Apri1, 1975.

Hodges, A. and Dorkin, H. "Location and Psychiatric Care," Public Health Reports, March, 1961.

Human Services in the Rural Environment Reader, Madison ivisconsin: University of Wisconsin, May, 1977.

Jones, J., et. al. "A Profile of the Rural Community Mental Health Center," Community Mental Health Journal, December, 1976.

Kraingel, C. F. and MacDonald, F. H. "Social Forces in Rural Communities of Sparsely Populated Areas," Agricultural Experiment Station Bulletin 647, Bozeman, Montana: 1971.

Lee, L., et. al. "Community Mental Health Center Accessibility," Archives of General Psychiatry, Vol. 31, 1974.

Loomis, B. Rural Social Systems, New York: Prentice Ha11, Inc., 1950.

Maddux, J. F. "Psychiatric Consultation in a Rural Setting," American Journal of Orthopsychiatry, November, 1953.

Malzberg, B. and Everett Lee. "Migration and Mental Disease," New York Social Science Research Council, New York City, 1956.

Person, P. H. "Georgraphic VAriation in First Admission Rates to a State Hospital," Public Health Reports, August, 1962.

Public Health Service: Health Care Initiatives, U. S. Department of Health, Education and Welfare, Bureau of Community Health Services, April, 1973.

Special Report, "The President's Commission on Mental Health: Assessing the Needs of the Nation," Hospital and Community Psychiatry, September, 1977.

Springer, H. "A Decade in Rural Psychiatry," Hospital and Community Psychiatry, February, 1971.

Thalu, M. "The Role of the Psychologist in a Traveling Psychiatric Clinic," Mental Hygiene, Spring, 1950.

Williams, M. "A Rural Mental Health Delivery System," Hospital and Community Psychiatry, October, 1975. 


\section{APPENDICES}

I Maps

A. Eastern Oregon Comprehensive Community Mental Health Center Catchment Area Population and Distances from Administrative Office in Pendleton.

B. Estimations of Chronically Mentally 111 Residing in The Catchment Area Per County.

C. Average Mileage to Mental Health Service by Chronically Mentally Il] cijents.

II Instruments

A. Release of Information.

B. Interview Schedule

C. Mental Health Clinic Questionnaire.

II Letters

A. Letter of Authorization from J. D. Bray, M.D. 


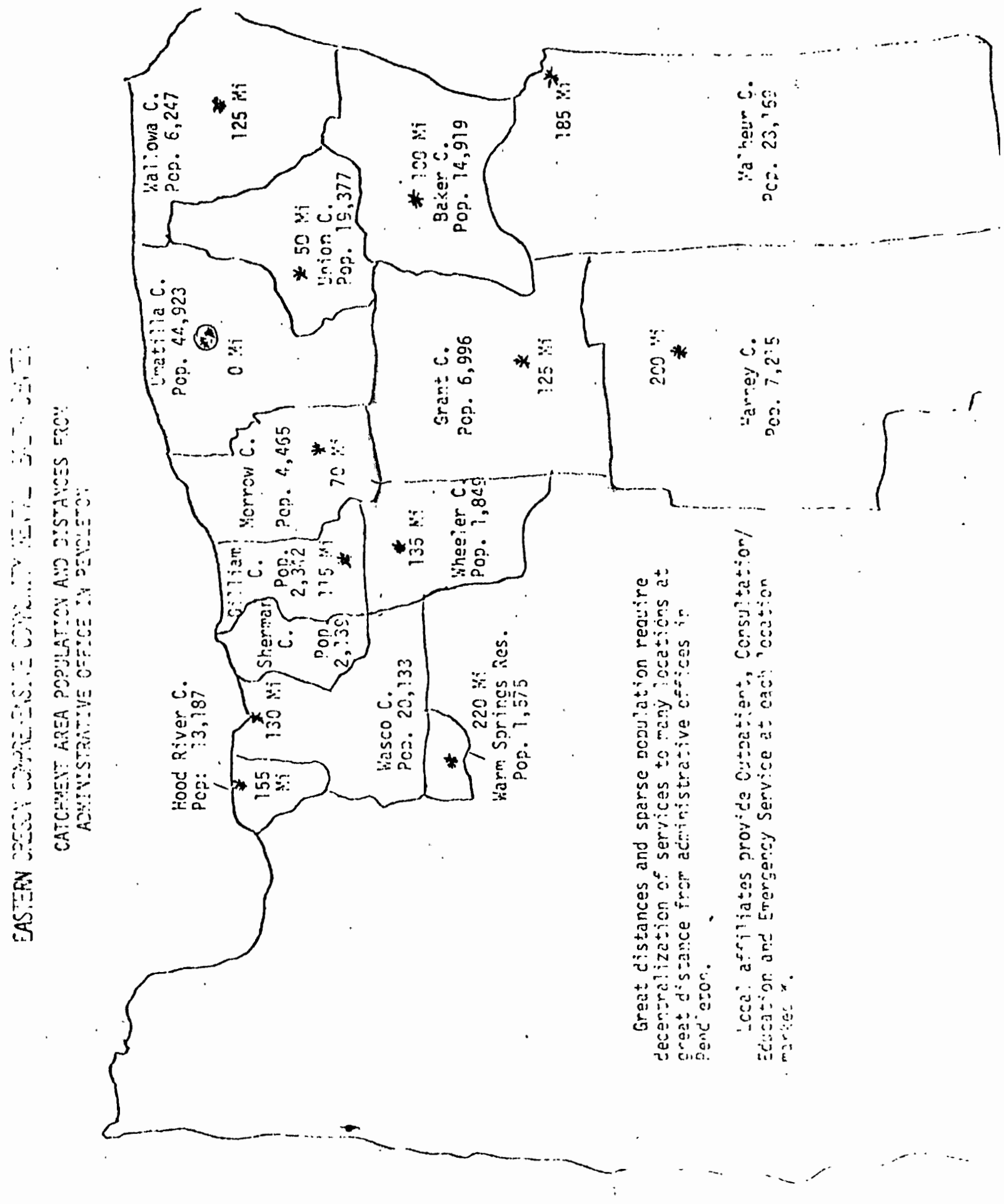




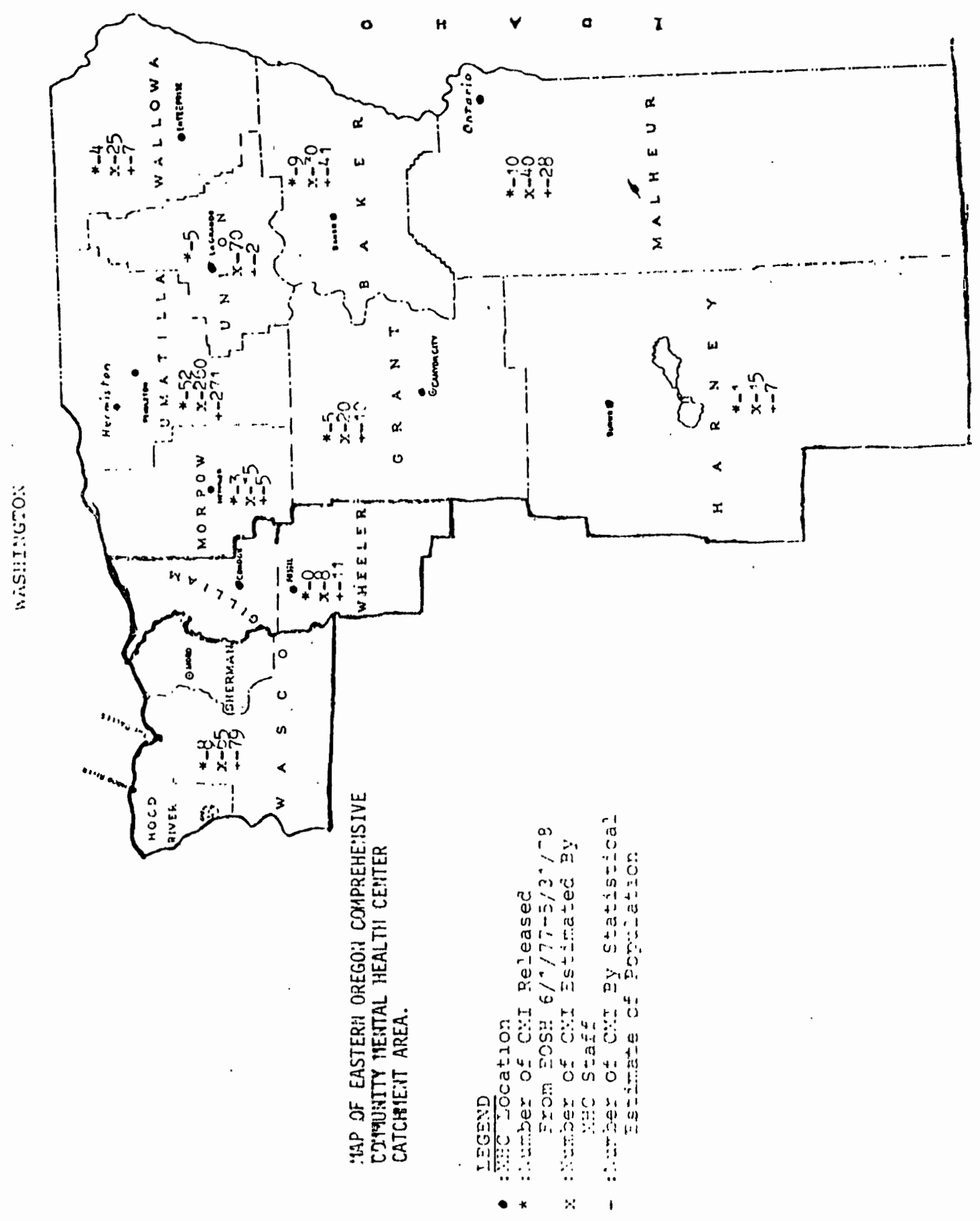




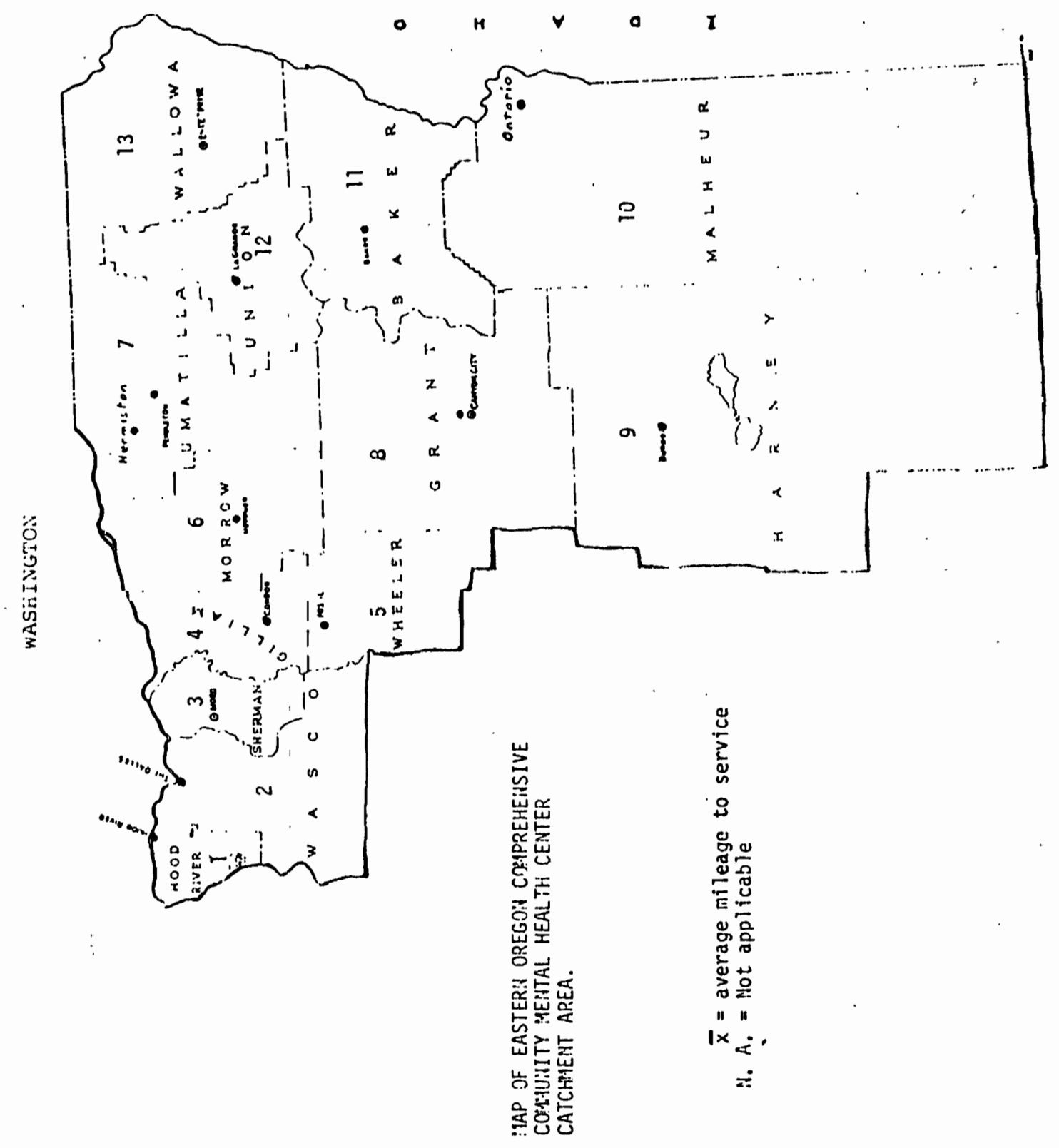

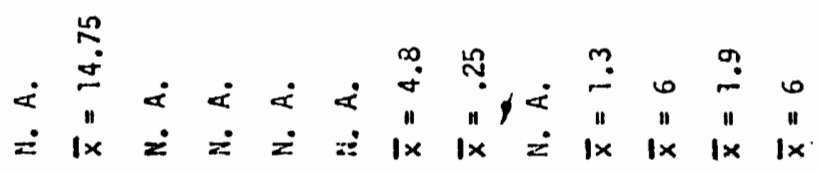

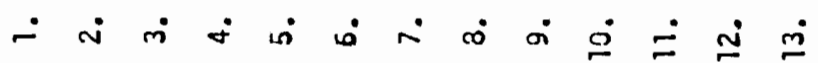


I grant permission to

(a research interviewer associated with the Community support Project of the Oregon State Mental Health Division), to a personal interview with me for the purpose of collecting information regarding the accessibility of mental health services to me. I understand that this information will remain anonymous to insure the confidentiality of the information I disclose. 


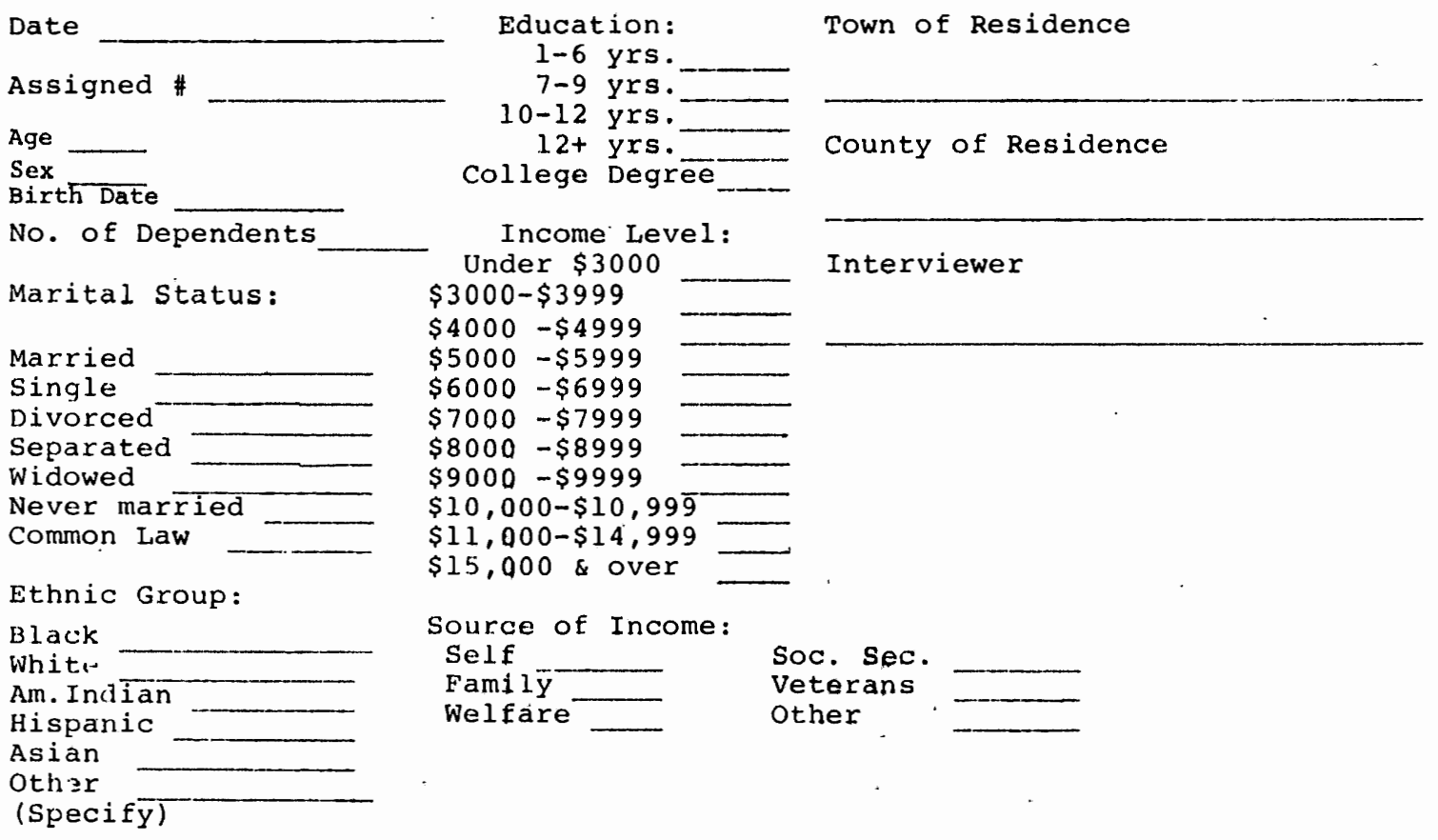

\title{
DATA FROM CLIENT'S STATEMENTS
}

1. Type of Residence:

Single Family Dwelling
Apartment
Hotel
Room \& Board Home
Intermediate care Facility
Cooperative house/apt. unsupervised
Cooperative house/apt. supervised

Sheltered Groip Home
Skilled nursing
facility
Transitionary group
home
Other

2. Present Living Arrangements:

\author{
Living Alone \\ Living with Family \\ Living with others (Explain):
}


3. Type and Location of Service:

Mental Health/Location

Adult and Family/Location

Medications/Location

Employment/Location

Other/Location

Describe:

4. Frequency of visit per month and place service transacted:

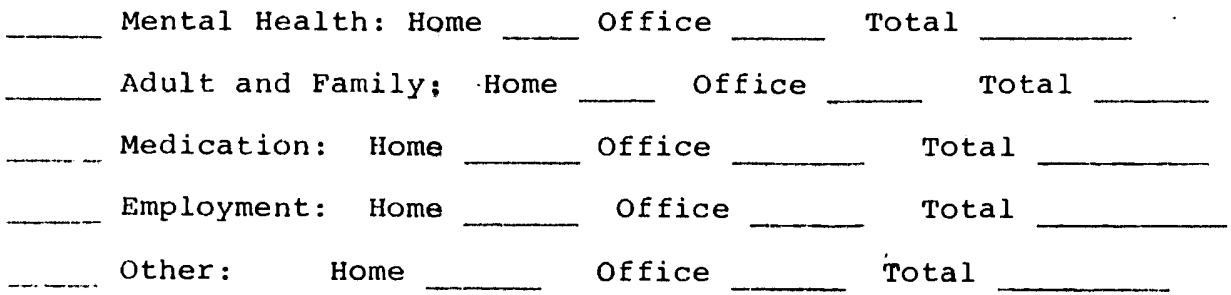

5. Health limitations of client with regard to transportation:

Vision

Hearing

Other/Describe:

6. Transportation used by client:

Self :

$\operatorname{car}$

Bus

Taxi

Hitchhike Walk

Relative:

Car

Bus

Tax

Hitchhike

Walk

Friend:

Car _ Bu

us ___ Taxi _._. Hitchhike

Walk

Neighbor:

Car

Bus

'axi

Hitchhike

Wa $1 k$

Other/Explain:

Car

Bus

Taxi

Hitchhike

Walk 
7. Transportation available to client: Self/car Relative/car Neighbor/car Friend/car

Bus

Taxi

Agency/car/Name Agency

\section{DATA FROM INTERVIEWER'S OBSERVATIONS}

1. Place of residence: Country (more than 2 miles from city limits) Town 0-250 (population)

\begin{tabular}{|c|c|c|}
\hline & Town & 0-250 (population) \\
\hline & $"$ & $251-500$ \\
\hline & $"$ & $501-1000^{\circ}$ \\
\hline & $"$ & $1,001-2000$ \\
\hline & $"$ & over 2000 \\
\hline
\end{tabular}

2. Type and location of service: Mental Health/location Adult and Family/location Medications/location Employment/location Other/location Describe:

3. Health limitations with regards to transportation: Vision Hearing Other/Describe: 
4. Geographic and climatic limitations with regard to transportation: Mountains/ passes closed from Paved highways Gravel highways Paved local roads Gravel local roads Dirt local roads Snow and ice in winter months Other/Explain:

5. Psychological limitations of client with regard to transportation: Free floating fear Specific fear/Describe:

Other/Explain:

6. Distance traveled for service: Mental Health/Distance Adult and Family/ Distance Mental Health Outreach/Distance Employment/Distance Other/Distance 
MENTAL HEALTI CLINIC QUESTIONNAIRE

1. How many chronically mentally ill clients does the clinic actively sec over one month duration? (average estimate)

2. Does the clinic have regular contact with the Eastern Oregon State Hospital? If so, how and when is this done?

3. What is the clinic's formal and informal policies regarding transportation for MIl sorvices ie. outreach, private transportation, etc.?

4. Additional comments regarding issues on transportation concerning the chronically mentally 111. 
July 13, 1978

Mr. Dale Poteet.

Portland State Untversity

School of Social Work

Post office Box 751

Portland, Oregon 97207

Dear Mr. Poteet:

This letter authorizes Tom H. Brubaker, Dayld M. Emmons, and John Meade, students in the Community Mental Health Project, Portland State University School of Soctal Work, to secure names and addresses of persons discharged from Eastern Oregon Hospital and Trafning Center during 1977 so the students may have access to these persons for follow-up interviews.

I understand the students are conducting a research project on transportation issues of the severely mentally disturbed in obtaining mental health services in Eastern Oregon. I also understand this research project is being done in conjunction with the Mental Health Division Community Support Strategy Development Project and as part of the students' requirement for the1r master's degree in social work.

The Information is to be gathered and the research completed by October 31, 1978. The students are to be supervised by you, Nancy Koroloff, and Dr. Dave Langenes.

$I$ am authorlaing this release of information in accordance with the provisions of ORS 179.505 (4)(b).

Sincerely yours,

$$
\text { J. D. Bray, M.D. }
$$

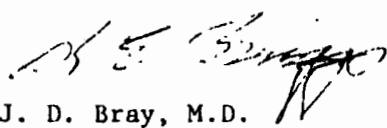

Assistant Director, Human Resources

Administrator of Mental Health

JDB: $18 m$

cc Elizabeth C. Brunette, Ph.D. Fred E. Letz, ACSW Joseph E. Murray Joseph H. Treleaven, M.D. 